\title{
Harald Halbhuber and Ewoud Hondius Guarantee Funds for the Travel Industry: Protection of the Consumer Against the Insolvency of His Organizer/Retailer
}

\begin{abstract}
One of the problems addressed by the EU Directive on Package Travel (1990) is that of travellers who find themselves stranded in their holiday destination when their tour operator suddenly goes bankrupt. The recent insolvency of Austrian and German tour operators illustrates the relevance of this question. This paper argues that travellers should be protected against the risk of insolvency of tour operators. The paper sets out the reasons for this, the various ways of insolvency protection, and the implementation of the Package Travel Directive. It then sets out what is secured by the guarantee, the obligations of the organizer and retailer, the cross-border implications, the possibility to choose freely the means of security, guarantee funds, insurance and social security, bonds and guarantees, trusts, and EC implications. It is argued that Member States should provide a higher standard of protection than the minimum standard of the Directive. A traveller should be entitled to compensation not only for immaterial damage but also for pure economic loss, such as the higher costs of an equivalent trip. The paper also argues that refund of prepayments should not be limited to the period before the trip has started. The traveller should also be reimbursed for extra costs incurred if he decides to stay at his destination. Finally, a traveller should be entitled to take care of his own repatriation, should he wish to do so. The paper finally argues that Member States should be held liable for late implementation of the Directive.
\end{abstract}

\section{INTRODUCTION}

\section{Aim of this Paper}

On 13 June 1990, the Council of the European Community adopted a Directive on Package Travel. Article 7 of the Directive requires travel agencies to provide securities that guarantee their customers sufficient compensation in case of bankruptcy. This article has resulted in travel guarantee funds being found on the agendas of all Member States of the European Union. The questions that have arisen are what alternatives may be offered to consumers, who should pay for the funds, and whether consumers should be represented on the boards responsible for the funds. This is not just a theoretical issue. The insolvency of two German tour operators before Germany had implemented the 
Directive, but after it should have done so, illustrates the importance of these questions.

Guarantee funds may be found in many trades and industries. Funds which are somewhat similar to those in the travel industry have been set up with regard to bank deposits, the building industry, building insulation, painters, and solicitors, among others.

It has been submitted by some authors that under the standstill provision of the Product Liability Directive, Member States are not allowed to establish funds. The 1995 evaluation of this Directive has not led to any change in this regard. Motor vehicle guarantee funds do generate a fair amount of case law, but these decisions involve issues which are quite different from the ones found in the travel industry. Even further removed from traditional consumer affairs are environmental funds and funds for crime victims.

In this paper, we will deal with what is secured by the guarantee, the obligations of the organizer and retailer, the cross-border implications, the possibility to choose freely the means of security, guarantee funds, insurance and social security, bonds and guarantees, trusts, EC implications, and state liability for late implementation. It will end with some conclusions.

Before going into these matters, we will first explore the following issues: why consumers should be protected against the insolvency of travel agencies, the various ways of insolvency protection, and the implementation of the Package Travel Directive.

\section{Reasons}

Why should consumers be protected against the insolvency of travel agencies?

It may be argued, against protection, that as a general rule everybody in business life bears the risk that his contractual partner may become insolvent. This allocation of the insolvency risk to the contractual partner seems appropriate because he has the freedom of choosing his counterpart. He may therefore assess the financial credibility of his debtor and, as a consequence, decide to enter a contract or abstain from doing so. There seems to be no reason why this risk should be borne by somebody else; yet this would be inevitably the result, if it were not allocated to the debtor's contractual partner. 
In favour of protection the following may be said: The counterarguments mentioned above start with the assumption that the financial trustworthiness of the counterpart is taken into account when concluding a contract. For consumers who book package travels, this is not likely to be the case. Rather than considering the economic situation and solidity of the travel agencies, consumers look for other features, especially good value. Thus consumers tend to choose travel agencies which operate with an especially low profit margin and which are consequently more easily subject to financial difficulties. Furthermore, because of a lack of access to information, consumers are rarely able to assess the insolvency-risk of the travel agencies. In any case consumers can hardly be expected to do so.

\section{Ways}

Many ways of insolvency protection may be conceived. The industry may set up a voluntary guarantee scheme on a private basis or one supported by the legislator. The legislator can prescribe a compulsory security but leave the "how" to the individual company or to an association of the industry. He may also restrict the choice to a limited number of means or even to one single solution. The beneficiary of the security may be the consumer directly or the company; in the latter case the consumer is protected indirectly since the system prevents his contractual partner from becoming insolvent. The beneficiary of the security can have the right (which he may enforce before a court) to payment or just the right to "ask" for payment. The security may be financed through the consumer, the company, or the state.

\section{Effects}

The effects of insolvency protection very much depend on the specific means of protection that is used. However, in any case, the risk is shifted from the individual consumer to somebody else, presumably a collective. It may lead to higher prices and distort competition. On the other hand, the consumer may feel safer when going on holiday and thus be able to enjoy it more. Details of the legal and economic effects will be discussed below. 


\section{Article 7 Package Travel Directive}

On the basis of Article 100a EEC, the Council of the European Community has adopted the Council Directive of 13 June 1990 on Package Travel, Package Holidays and Package Tours. ${ }^{1}$ The deadline for national implementation was 31 December 1992. ${ }^{2}$ The Directive gives guidelines for national legislation on package travel. Among others, it contains a provision for the protection of the consumer in case of insolvency of the organizer and/or retailer of the package.

So far notifications of implementation have been received by the Commission from Austria, ${ }^{3}$ Belgium, ${ }^{4}$ Denmark, ${ }^{5}$ France, ${ }^{6}$ Germany, ${ }^{7}$ Italy, ${ }^{8}$ Luxemburg, ${ }^{9}$ the Netherlands, ${ }^{10}$ Portugal,${ }^{11}$ Sweden, ${ }^{12}$ Switzerland, ${ }^{13}$ and the United Kingdom. ${ }^{14}$ Denmark has not implemented the whole Directive yet, but already had a compulsory insolvency protection system ${ }^{15}$ before 1990 . In the remaining EC Member States only voluntary schemes exist (if at all). In Spain, special difficulties are said to arise because this field of legislation falls within the competence of the regions (Lopéz Sanchez, 1994, p. 94; Tonner, 1993a, p. 198). The delay in implementation might give rise to liability for the Member States in question. ${ }^{16}$ Norway had travel guarantee schemes ${ }^{17}$ long before the Directive and the current situation there will be considered as well.

\section{THE STANDARD OF PROTECTION}

\section{Amount of Protection}

General considerations. Full protection can be said to exist where the situation for the consumer is the same as it would be if the organizer/retailer ${ }^{18}$ had not become insolvent. This can be achieved in various ways.

The organizer/retailer may be given some financial support (in other words, payment) so as to prevent him from actually becoming insolvent. This solution affords the consumer sufficient protection: The travel takes place as planned; the consumer may not even realize that the organizer/retailer has financial difficulties. Yet it poses problems concerning competition and market efficiency.

Another way is to transfer the contractual obligation of the insolvent organizer/retailer to another person, be it a security institution or another organizer/retailer. Practical problems might occur when this 
new person tries to organize an equivalent package. A legal problem is posed by the consumer's freedom of contract - is his consent needed for the transfer of the obligation?

The consumer could book an equivalent trip elsewhere and get reimbursed for his costs. Considering the liability of the organizer/retailer under the Directive, ${ }^{19}$ this is an insurance for his liability for the cancellation of the trip.

The same holds true if the insolvency occurs after the trip has begun: All claims the consumer might have against the organizer/ retailer for improper performance of the travel contract or damages he has suffered could be secured against the case of insolvency.

The minimum standard of the Directive. After having discussed the highest conceivable amount of protection, we shall now turn to the minimum standard prescribed by the Directive. The Directive defines "refund of money paid over and repatriation of the consumer" as the minimum level of protection the organizer/retailer should provide.

When the trip has to be cancelled before it has even started, the payments the consumer has already made should be returned to him. He is deprived of his journey, but the refund may enable him to book another one. However, it should be borne in mind that he may not only suffer immaterial damage, but also tangible financial loss: An equivalent trip might be more expensive elsewhere. Yet a "refund" does not cover these expenses - a "refund" can never be more than a mere return of money the consumer has already paid, it is not a claim for damages! The amount of the refund is indicated by Article 4(6) of the Directive: It can either be the full amount of all prepayments ${ }^{20}$ or just a part of it. The latter is the case whenever the organizer/retailer offers a cheaper replacement package and therefore has to refund the difference in price. ${ }^{21}$

Once the consumer is at his holiday destination a refund claim is conceivable in two cases. First, when the trip is shorter than planned. Second, when the terms of the contract are not performed properly in some other way, e.g., the hotel is of a lower standard, there is no swimming pool, extra payment for meals, mice in the bedroom, etc.

It has been proposed that prepayments be refunded only before the trip has started (Kemper, 1993, p. 3295). Afterwards the protection of the consumer should be limited to repatriation. Such an approach seems in line with the wording of the Directive: The term "refund" is used only with regard to the cancellation of the package 
before the agreed date of departure. ${ }^{22}$ Nevertheless it appears very unjust: There is no justification for making a distinction between cases where the trip has to be cancelled one day before departure and those cases where problems arise after the scheduled departure (Schimke, 1993, p. 702). In the first case the consumer would not receive any services but would receive a full refund of his payments. In the second case the consumer would receive almost no services but would not get any refund.

How then should refund after departure be calculated? To answer this question it is helpful to look at the legal nature of such a refund claim. The Directive itself clearly distinguishes between "compensation" which is based on the "difference between the services offered and those supplied"23 on the one hand and a claim for "damage resulting for the consumer from the failure to perform or the improper performance of the contract" 24 on the other. Both the "compensation" for "difference of services" after departure and the "refund" claim for "difference in price" of a replacement package before departure are based on the concept of a certain relation between performance and price; thus it seems possible to include both in a broader concept of "refund." Considering that the refund granted for a difference in price will be due to the lower quality of the cheaper replacement package (which is provided before departure), granting a refund for lower quality seems well in line with the concept of the Directive.

This leaves the question of a package that has to be terminated after departure. It may be of the stipulated quality, but is shorter than agreed upon in the contract. Here the connection between services not performed and the price paid for them is even more obvious; if the actual trip is, for instance, only half as long as planned, it seems appropriate to grant a "refund" for the part of the price that relates to the remaining half (Graziani-Weiss, 1995, p. 156; for the opposite view, see Kemper, 1993, p. 3295).

In practice, a consumer who arrives at his destination only to be denied accommodation because of the organizer/retailer's insolvency, may either decide to take the next flight home - in this case he would be refunded the money he has prepaid plus the cost of the flight or he may wish to stay at his destination and pay for his accommodation himself. In most cases, this is what happens. Once back home the only option that may be open is to stay at home! He will not be able to book a new package trip for the same period of time, his holiday may be already half over. Can he be reimbursed for his extra 
costs if he decides to stay at his destination? Unfortunately not under the minimum regime of the Directive. The only compensation is refund of his prepayments, plus a free repatriation.

It is important that the cost of repatriation is not deducted from the refund of the package price! At first sight this may seem to be an extra bonus for the consumer, because transportation is part of the package. Yet this is exactly the reason why refund of the package price and repatriation are completely independent of each other. Transportation to a holiday destination does not in itself have any value for the consumer if he is deprived of accommodation (Schimke, 1993, p. 702); it remains an inseparable part of the package.

Security for the repatriation of the consumer can either be an actual organization of the transport or a refund of the costs incurred by the consumer for this purpose. The wording "for the repatriation of the consumer" seems to indicate that the Directive prescribes the former, but from the travaux préparatoires to the original proposal it becomes clear that a refund of the costs of repatriation is considered sufficient (Graziani-Weiss, 1995, p. 55). Indeed, it does seem a lot more practical to have the consumer take care of his repatriation himself. Administration is much easier when the consumer himself finds a means of transport and gets reimbursed for its costs back home.

Member States legislation. These different amounts of protection are reflected in Member States legislation. In Germany the implementing provision $^{25}$ provides for the refund of the price that has already been paid, in as far as services are not performed because of the insolvency or bankruptcy of the organizer/retailer. In addition to this, necessary costs incurred by the consumer for repatriation as a consequence of the insolvency or bankruptcy of the organizer/retailer shall be refunded.

In the Netherlands the relevant provision ${ }^{26}$ demands that either the obligation of the organizer/retailer be transferred to another person or that there be a refund of the price. In any event the repatriation of the consumer has to be "taken care of," which seems to cover actual transport arrangements as well as a refund of its costs. The preparatory documents to the Dutch Act state that "as a matter of fact" the costs of repatriation can be deducted from the refund of the price. ${ }^{27}$ The Dutch SGR (a guarantee fund for the travel industry) refunds prepayments if one of its members, as a consequence of "financial 
inabilities," cannot fulfill his obligations (Mölenberg, Olivers, \& Hallmans, 1990, p. 346).

In Denmark the law specifies four services ${ }^{28}$ of the (obligatory!) guarantee fund. The prepaid amount is refunded if the trip cannot start because of the organizer/retailer's financial difficulties. Repatriation of the consumer is arranged by the fund. The fund also grants "reasonable compensation" for a fundamental breach of contract during the trip. Accommodation abroad can be arranged, but the consumer has no enforceable right to it.

In the United Kingdom the implementing law takes over the wording of the Directive. It adds that for the purpose of refund of prepayments "a contract shall be treated as having been fully performed if the package ... has been completed irrespective of whether the obligations under the contract have been properly performed." ${ }^{29}$ Liability for defective performance is dealt with in the implementing act, ${ }^{30}$ but not in the context of insolvency protection. This seems to indicate that lower quality of performance does not lead to a refund claim of the consumer.

Austria implemented part of the Directive first, but waited some time (why?), before issuing an ordinance concerning insolvency protection. The ordinance states that the security must cover the refund of prepayments, in the event of services not performed due to the insolvency of the organizer/retailer. The security must also cover all necessary costs incurred by the consumer for his repatriation. These can be the price of a ticket, a night spent in a hotel (waiting for the next available flight), telephone calls, etc. (Graziani-Weiss, 1995, p. 151).

Like many other implementation laws, the Swiss one restricts itself - more or less - to repeating the words of the Directive, namely that the organizer/retailer has to guarantee "... the refund of money paid over and the repatriation of the consumer ...", which has given rise to criticism, because it "raises more questions than it answers" (Roberto, 1994, p. 7).

At first sight, the Italian decree implementing the Directive seems no better in this respect: It plainly provides for securing the refund of prepayments and the repatriation of the consumer, yet all the questions remained unsolved and are left to scholars and judges. The decree demands a compulsory civil liability insurance of the organizer/retailer; thus the insolvency guarantee will become relevant only in cases where refund claims or the costs of repatriation remain 
unpaid by this insurance (e.g., if the organizer has failed to take one out or has not paid his premiums).

Portugal has a very consumer-friendly implementation. The security that the organizer/retailer must provide covers not only the refund of prepayments and the repatriation of the consumer, but also additional expenditures incurred by consumers as a consequence of non-performance or defective performance on behalf of the organizer/retailer. Furthermore it covers reimbursement to the consumer for any damage inflicted upon him by the organizer/retailer or its agents. In this case detailed provisions about the amount of protection and sophisticated distinctions between types of refund seem superfluous, as they are all covered by the security.

The Norwegian guarantee scheme covers refund of prepayments if the tour has to be cancelled, as well as expenses for repatriation, including overnight stay and other necessary expenses if the tour is terminated after departure.

\section{Obligations of Organizer/Retailer}

The Directive. According to the Directive the organizer/retailer can organize the security himself or take advantage of a public scheme that covers all consumers. His duty towards the consumer is only to make sure that the consumer is protected and perhaps also to inform him about the kind of security. Any other obligation concerning the "how" of the protection - for example participation in a guarantee fund, insurance company coverage, payment of premiums, etc. involves only third parties such as the state, a fund, an insurance company, etc.; always provided that the consumer is sufficiently protected.

The Directive states that the organizer/retailer shall "provide sufficient evidence of security." The meaning of this wording is twofold: It implies a duty to make sure that the consumer is protected by sufficient security, and it expresses the obligation to prove this security to someone. Thus the Directive makes the provision of security the task of the organizer/retailer, but it does not state explicitly that he also has to pay for it.

The wording seems to point to some public authority that checks the provided evidence (Roberto, 1994, p. 16; Tonner, 1992, p. 283). To "provide evidence" is something done in court, in an administrative proceeding, in any case before some sort of official institution that 
decides about the sufficiency of the evidence presented. The supervising authority included in the original proposa ${ }^{31}$ has been omitted in the final version of the Directive, which has been used as an argument to suggest that the organizer/retailer has to provide the consumer with evidence of security (Meyer \& Kubis, 1993, pp. 213-214).

The aim of Article 7 of the Directive is to protect the consumer. Every possible interpretation has to be judged with regard to this aim.

In case the organizer/retailer is free to choose his means of securing the consumer and the consumer is protected only by this security and not by a guarantee scheme which protects consumers even if the organizer/retailer has not provided sufficient security - the lack of a supervisory authority inevitably leads to insufficient protection of the consumer. The consumer is unable to decide for himself whether the "evidence" provided by the organizer/retailer is indeed evidence of anything. The argument that the consumer should be able to decide how much security he wants ${ }^{32}$ is not valid, as it reduces consumer protection to a mere duty to inform. In our opinion the Directive demands more.

Where security may be provided only by a limited number of means, the situation is different. State control intervenes at an earlier stage in deciding in abstracto which kinds of security are sufficient and what constitutes sufficient evidence of such a security. Here the consumer has only to ask the organizer/retailer to show him one of the few proofs accepted by the law, and his protection will be clearly enhanced.

According to the proposal for the Directive, Member States had to ensure that a guarantee fund was available. Yet the final version demands only that Member States require organizers/retailers to provide security for the consumer. It does not say that Member States have to provide this security themselves. This means they are not obliged to protect the consumer against the eventuality that the organizer/retailer has not provided any security at all or that the security provided turns out to be insufficient (Löwe, 1993, p. 1435; Solveen, 1994, p. 62; contrary, Eckert, 1994, p. 458; Tonner, 1993a, p. 202). Nevertheless, it would not suffice if Member State legislation demanded that the organizer/retailer ensure sufficient security but failed to enforce this obligation by adequate sanctions and control. Fines will serve this aim effectively only if they are prohibitively high 
or are combined with other measures, such as loss of licence to trade.

Yet Member States are not prevented from ensuring indemnification of the consumer even in cases where the organizer/retailer has failed to do so.

As indicated above, the Directive does not pronounce on what constitutes a "sufficient evidence of security." Of course this wording must not be construed so narrowly as to express that only the evidence has to be sufficient. Sufficient evidence of an insufficient security would be useless and not serve the aim of consumer protection. Therefore the security itself has to be sufficient; in our opinion it may be called so only if it affords the consumer an individual right (Führich, 1994, p. 2449; Huff, 1994, p. 446; Tonner, 1993b, p. 1208).

Thus a scheme that effects payments to the organizer/retailer or a trade organisation is considered to be sufficient, only if it retains a claim against the respective receiver of the payment. This claim has to enjoy priority over claims of other creditors of the organizer/retailer.

Member States. Let us now turn to the situation in different Member States. According to the German Act, ${ }^{33}$ the organizer/retailer "has to ensure that the consumer is reimbursed for . . ." ${ }^{34} \mathrm{He}$ can only fulfill this obligation by providing an insurance or a bank guarantee. Furthermore he has to supply the consumer with proof of a direct claim against the insurance company or bank by handing over a certificate of the respective company. ${ }^{35}$ Before he has done so he is not allowed to accept consumer payments of more than $10 \%$ of the price or DM 500, whichever is higher. The sanction for breach of this provision consists of a fine of up to DM 10.000 for each prepayment received. ${ }^{36}$

In the Netherlands, the law obliges the organizer/retailer "to take measures necessary to ensure that . ..." The organizer/retailer has to make known the measures he has taken in brochures, other publications, or in any public way. Obviously the Dutch legislator believes in the force of the market. He considers information to the consumer to be the most important item and trusts that the consumer will take this information into account when booking his trip. Consequently, as it appears from the preparatory documents ${ }^{37}$ sanctions are provided only for false information.

In Denmark, every organizer/retailer has to be registered with a guarantee fund. Only organizers/retailers that have been registered are 
allowed to deal in package travel. The sanction consists of a fine, notwithstanding the application of criminal law.

In the United Kingdom, the organizer/retailer "shall at all times be able to provide sufficient evidence of security for the refund of money paid over and for the repatriation of the consumer in the event of an insolvency." 38 This follows almost the exact wording of the Directive. The organizer/retailer must ensure that at least one of the following arrangements is in force: a bond by an authorised institution, an insurance with direct coverage for the consumer, or a trust for consumer prepayments. Compliance with these regulations is reinforced by fines. As far as we can see the security for repatriation is mentioned only in very general terms and not referred to at all in the regulations concerning the various security schemes in which only the refund of prepayments is mentioned.

The Swiss implementation act enshrines an obligation of the organizer/retailer to guarantee the refund of money paid over and the repatriation of the consumer. Regrettably, it neither gives any more precise information about the amount or means of this guarantee, nor provides for any kind of supervision. The only sanction is the right of the consumer to abstain from the contract if the organizer/retailer is unable to provide evidence of such a guarantee.

Under Austrian law, the only way the organizer/retailer may provide security is by an insurance-contract or a guarantee from a bank or a public entity (e.g., the chamber of commerce). The minimum insurance sum is $5 \%$ of the organizer/retailer's turnover in the respective quarter of the previous year. The consumer must obtain a direct claim against the insurer. In addition, this claim has to be independent of whether the securing institution might be free from its obligation towards the organizer/retailer. For instance, even if the organizer/ retailer has not paid his last premium, the consumer must remain secured. The sanction for not providing such a security is, apart from a rather ridiculous fine, a very effective one, viz., the organizer/retailer risks losing his licence.

Portugal has very detailed provisions regarding the obligations of the organizer/retailer. For the refund of prepayments and additional expenditures caused by non-performance or defective performance of the travel contract, the organizer/retailer must supply a guarantee in the form of an insurance, a bank guarantee, a bank deposit, or another means approved by the Director-General of Tourism. For the reimbursement for damages and the repatriation of the consumer the 
undertaking must take out a civil liability insurance. These obligations are accompanied by a supervisory mechanism under the authority of the Director-General of Tourism. Sanctions range from a fine to the suspension or complete loss of licence to trade.

In Italy, too, the implementing law provides for a civil liability insurance. In addition, it institutes a national guarantee fund which secures the refund of prepayments and the repatriation of the consumer.

The Norwegian guarantee scheme has two components. The organizer/retailer must provide an insurance or a bank guarantee. In addition, he has to pay a certain contribution to the travel guarantee fund, which has been instituted by law. The amounts of both components depend on the turnover of the undertakings.

None of the above-mentioned laws or proposals includes any reference to the nationality of the consumer and would seem not to prejudice his rights for that reason. Any discrimination on the ground of nationality is in any case prohibited under EC law..$^{39}$ The protection of the consumer depends on the law his contractual partner is subject to, i.e., which criteria must be met. According to the principles of EC law, this should be the law of the company's place of establishment.

\section{DIFFERENT MEANS OF INSOLVENCY PROTECTION}

\section{Freedom of Choice}

The legislator can give the organizer/retailer the possibility to choose freely the means of security he considers suitable or can restrict his choice to a limited number of means.

Free choice for the organizer/retailer has the advantage that the operation of already existing schemes can be continued without changing their legal status or their organization. In addition, it utilizes the free market to create a variety of securities with different features so that every organizer/retailer can pick the one most suitable for his size and kind of business. The market will test these various schemes, and they will therefore evolve and adapt to the needs of industry as well as consumers.

It seems, though, that the ability of the market to shape different kinds of security may be doubted. It is hard to conceive that organizers/retailers will use the features of their insolvency protection to 
market their package tours. Experience in selling optional insolvency insurances to consumers supports this concern.

A limited number of security means from which the organizer/ retailer has to choose makes it easier for the consumer to judge a security he is offered, but limits the role of the market while giving considerable economic power to the institutions which provide the security.

\section{Guarantee Fund}

The big advantage of a guarantee fund compared to securing consumer claims by insurance is that it affords the same protection at lower cost, because the administration costs and especially the profit margin of the insurance companies do not have to be paid for.

A guarantee fund may be financed through the consumer: for example he can pay a contribution when he books a trip. This seems appropriate, because he is the one who benefits from the fund, his claims are secured. A possible disadvantage of this kind of financing is the lack of incentive for the organizer/retailer to keep the costs of the fund low, i.e., not higher than the necessary level. Where consumers participate in the fund, they should also have a say in its administration.

The fund can just as well receive its resources from the organizer/retailer. Such an approach could be justified by saying that after all it is the undertakings that go bankrupt and cause all the trouble. Although the costs of financing the fund would be shifted to consumers through higher prices, this seems more cost-effective, because the contributions to the fund are actual costs for the organizer/retailer which they themselves can influence. By decreasing the costs the undertaking can either increase its profit margin or its share in the market, depending on whether it upholds its prices or cuts them. Thus undertakings would press for low costs of the insolvency protection. As stated above, the Directive is not clear on the issue of financing security. Consumer organizations argue that it is incompatible with consumer protection, as the main goal of the Directive, to have the security - whatever form it may take - financed by consumers.

Payments from the fund could be addressed to the organizer/retailer who has become insolvent or who is in financial difficulties. This will satisfy consumer protection, as the organizer/retailer will not 
become insolvent in the first place. Furthermore it is said that reducing the number of insolvencies stabilizes the whole industry (as for the banking sector, see Möschel, 1983, pp. 626-627). The problem is that payments to insolvent companies are hardly compatible with the regulatory function of a free market (Dreher, 1993, p. 1619). Organizers/retailers that have turned out to be unfit for competition should not survive. If they do, the increase in the number of inefficient companies will probably destabilize the market in the long run. Such payments reward risky conduct and unfair competition; undertakings are likely to trade at very low prices, hoping to make up for them by the number of packages they sell. Through a scheme that grants them payments in the case of financial difficulties they are able to operate below cost-level without bearing the risk for doing so.

Another question is whether the beneficiary of a given security (whoever he may be) should have the legal right to receive benefits which he could enforce before a court, or just the non-committal possibility to ask for them, leaving the decision to the discretion of the administration of the security-providing institution in question. The answer to this question is not only a matter of policy, but could pose a technical problem: Where the beneficiary of the security-providing institution has an enforceable right to benefits in exchange for premium-like payments (no matter who makes them), that institution will easily constitute an "insurance" under national law. Insurance law usually provides for a full-fledged legal regime, including the requirement of certain corporate forms for the company as well as a sophisticated supervisory and control mechanism. But this should not be a disadvantage: Of course, a guarantee fund can be set up in the form of an insurance. However, an individual right seems indispensable under the regime of the Directive in order to provide sufficient security.

The main problem with guarantee funds is constituted by their anticompetitive tendencies: On the one hand, setting up a guarantee fund pays off only if it covers the better part of the market (Tonner, 1992, p. 281). On the other hand, exactly this feature tends to abolish competition - not among travel organizers, but between the providers of security, e.g., insurance companies. There is only one important provider, the fund itself $!^{40} \mathrm{~A}$ guarantee fund run by the travel industry itself could easily tempt unfair practice among travel companies themselves (Solveen \& Tonner, 1994, p. 79): An undertaking may have 
to disclose very sensitive information to the administrators of the fund, information which could easily be abused by any competitors who might sit on the board of the fund.

\section{Insurance and Social Security}

Private insurance. Insurance can be taken out by either party of the travel contract and with either party as the insured beneficiary. Solutions where payments are made to the insolvent undertaking can probably be ruled out because of their anti-competitive effect.

The question of who should pay for the security in general shows a new facet in the context of insurance. Apart from the difficulties experienced with marketing an insurance to the consumer, an insurance bought by him is not a very good solution from a competitive point of view either. An organizer/retailer will usually sell a standard insurance package from one company with which he cooperates. The consumer choosing a certain travel package from that organizer/retailer will not, in fact, have a choice between different insurers. Thus competition among insurance companies is eliminated.

If the enterprise is to take up the insurance (of the consumer, i.e., the latter is the insured person), competition is more likely to occur, but as experience with other kinds of compulsory insurance have shown (e.g., liability insurance for car drivers), state control of prices might still prove necessary.

Another problem with insuring insolvency is the assessment of the insolvency risk. A thorough examination of an undertaking with regard to its financial resources and performance is a costly effort, which would put insurance beyond the means of some small undertakings. To avoid such a time-consuming examination the insurance company could just ask the travel business for a self-assessment, but this higher risk would inevitably result in higher premiums.

While the disadvantage of an insurance is avoided in a guarantee fund, because the bigger participants bear in part the risks of their smaller competitors, such a character of solidarity which a fund has might not be desirable from an economic point of view. Enterprises that are not able to survive on their own should not be allowed (or even forced!) to burden their competitors with their inefficiency.

Dealing again with the question of financing, it may be of interest to ask which approach will lead to higher economic efficiency, i.e., who should be made to pay for the insolvencies in order to decrease 
their number. The costs of a future insolvency will have an impact on the conduct of a business if the business itself has to bear them. Consequently an insurance financed by premiums that are calculated on the basis of the insolvency risk that an enterprise carries, and paid for by the enterprise itself, seems to be a wise solution. Where their business renders enough profit to pay the costs of their potential future insolvency, this is fine. Where it does not, they will either adapt to a less risky conduct or be driven out of the market. In any case this should reduce the number of insolvencies.

Social security. Social security does not seem an appropriate means of dealing with the insolvencies of package travel companies. Furthermore it seems problematic with respect to the provisions of the EC Treaty concerning state subsidies (Dreher, 1992, p. 1601).

\section{Bonds and Guarantees}

Guarantees and similar financial instruments offer a way of providing insolvency protection that is especially attractive for large companies who are able to obtain such guarantees from their main shareholders at no cost (Führich, 1993, p. 351), but that may be more difficult to get for small and medium-sized businesses. In any case banks have the expertise to assess a company's conduct and its assets.

Putting consumer prepayments in a trust certainly does give sufficient protection against insolvency, but has two disadvantages. First, the money put in trust may not suffice for repatriation, either because the consumer retains a refund claim even after departure or because the costs of repatriation are higher than the costs of the package. The second obvious disadvantage of a trust is that the travel agency is not able to use the money while it is in trust. This brings us to a question which is crucial for the whole issue of securing consumer prepayments: Does the consumer have to make prepayments in the first place?

\section{Member States}

In Denmark, a compulsory guarantee fund for the package travel industry has been set up by law. $\S 1$ states that the fund is a private institution, "owned by itself." Every organizer/retailer of package 
travels has to be registered with the fund. For this registration a bank guarantee of DKK 200,000 is required. New undertakings must register in the fund before they are allowed to start their activities. The fund is financed through a contribution of DKK 5 for each trip sold. Payments to consumers are first taken from the bank guarantee of the insolvent undertaking. Amounts not covered by the bank guarantee are paid from the reserve the fund has accumulated from the DKK 5 contributions. The administration costs of the fund are paid from the DKK 5, too. The fund is run by a board of three persons, appointed by the Minister of Industry for a period of three years. The chairman of the board must have the legal qualifications of a judge, while of the other two board members one represents the consumers and one the travel industry.

In the Netherlands, $98 \%$ of the organizers/retailers participate in the voluntary SGR. Membership is open for every undertaking that fulfils the fund's requirements of solvency and liquidity, which are secured by annual controls. Furthermore, each participant must supply a bank guarantee for the amount of $45 \%$ of its annual turnover. The participating companies sell guarantee certificates to consumers with each trip. The price of such a certificate is NLG 10 , of which only NGL 5 go to the fund. The remaining NGL 5 are kept by the company for the costs of marketing the certificate. The fund is consequently financed entirely by the consumers; the companies just bear the costs of administration. Nevertheless consumers or their organizations do not have any say in the management of the fund, as only the travel industry and the government are represented in the fund. Over the years the SGR has accumulated a considerable sum, possibly higher than would be needed to cover the risks concerned. This, as well as the lack of consumer participation, has given rise to criticism. It has even been argued that the SGR in fact conducts an insurance business without having the required legal corporate form, which would render the SGR illegal and its legal acts void.

The German travel industry association and a major German insurance company have submitted a joint proposal for the establishment of a guarantee fund in Germany. According to the proposal, it would be organized in the form of a "pool," the shares of which are bought by insurance companies. This would also solve the problem of meeting the strict regulations for the insurance business under German law, as the participating insurance companies already have the required licences and the technical-legal know-how. Participation would be 
open to all travel undertakings that fulfill some minimum requirements concerning their financial well-being. Larger companies could be subject to examination whereas small and medium-sized enterprises would just be asked to assess themselves. This lack of control is partly made up for by the bank guarantee for a certain percentage of their annual turnover which each participating travel company has to supply. The fund would be financed by consumer contributions, probably organized from the sale of guarantee certificates. Part of the money raised in this way would constitute the means of the fund; the rest would be used to buy insurance in case the means of the fund should not suffice. While the fund is thus financed by the consumers, it is owned and controlled by insurance companies. So far, such a pool has not been established, mainly for two reasons: fears for its anti-competitive effect and, quite bluntly, an understandable lack of solidarity in the industry. The big companies which can obtain guarantees at almost no cost from their main shareholders (banks or insurance companies) do not want to pay for the risks of the small ones (Tonner, 1993b, p. 1210).

The national Italian fund set up by the implementing law is financed through an annual contribution of $0.5 \%$ of the premium of the under Italian law - mandatory civil liability insurance. Details are to be regulated by ministerial decree.

In the UK, a discussion similar to the one in Germany took place. The situation in Britain ${ }^{41}$ before the Directive displayed funds of the ABTA which only covered air-travel abroad. Now these ABTA funds have been adapted, a new fund for the bus companies has been founded, and the AITA, a smaller rival organization to the ABTA, has its own fund. Insurance has no importance on the British market.

In Austria, the travel industry is not quite happy with the new regulation and will try to negotiate some alterations. The idea of a guarantee fund met with little enthusiasm in the big companies, which were unwilling to pay for the risks of their smaller competitors; they prefer to obtain individual insurance coverage. The existing guarantee fund of the Chamber of Commerce could be adapted to the standard of the Directive (Graziani-Weiss, 1995, p. 155).

In Norway, every organizer/retailer obtains his own insurance or bank guarantee but, in addition, pays annual contributions to the Travel Guarantee Fund. The fund manages the individual securities provided as well as the money raised through contributions. In case 
of insolvency the security of the individual company is used first, while the accumulated contributions are used to cover refund and repatriation costs that surpass those individual securities.

A similar scheme is employed in Sweden, where it has been criticized that the individual securities are too expensive and that the administration of the fund is unnecessarily complicated.

\section{IMPLICATIONS OF EC LAW}

The European Commission has favoured a system of insurances and bank guarantees rather than a compulsory guarantee fund, because such a fund might raise problems with the Freedom to Provide Services and the competition rules (Führich, 1993, p. 351; Solveen \& Tonner, 1994 , pp. $76 \mathrm{ff}$.). In the following - far from attempting to produce a full treatise of the matter - we shall try to outline the relevant Community rules and to indicate where problems with guarantee funds may arise and what guidelines can be given as to how an infringement of these rules can be avoided.

The EC legislation is concerned with trade restrictions in a broad sense of the word. This requires a definition of the relevant markets. In our case we can distinguish two markets, one for selling package travels and the other for selling insolvency protections.

\section{Freedom to Provide Services}

The first provisions we have to take into account are Article $59 \mathrm{ff}$. EC, aimed at securing the freedom to provide services. In particular Article $62 \mathrm{EC}$ states that Member States must not put any new restrictions on this freedom. A restriction could result from a licensing procedure, certain minimum requirements in general, or a monopoly ${ }^{42}$ which is managed or protected by the state.

It is generally assumed that the freedom to provide services is absolute, i.e., protected against restrictions of any kind, not just discriminatory ones. The European Court of Justice established this principle in the case of "Säger v. Dennemeyer,"43 where it clearly said that Article 59 EC does not only prohibit discrimination (on the basis of nationality), but demands the removal of all restrictions - even if indiscriminately applied - that may prevent or burden the provision of services by a person who is established in another Member 
State. The Court furthermore states that to require a licence (in case of a professional qualification) amounts to a restriction under Article $59 \mathrm{EC}$ and has to be justified by imperative reasons relating to the public interest. The Court also defines the preconditions for such a justification: Restricting regulations have to be applied to all persons operating within the territory of the Member State, but only insofar as the interest pursued is not safeguarded by regulations a person is subject to in his Member State of establishment.

Therefore a restriction on the freedom to provide services has to be tested as follows:

1. Is there a general interest which the restriction aims to protect?

2. Is this general interest not already protected by regulations in the Member State of establishment?

3. Can the protection be achieved by less protective means?

The parallel to the "Cassis" case law of the Court with respect to the free movements of goods is obvious (Roth, 1993, p. 152). Question 3 requires the same proportionality test (Randelzhofer, 1992, notes pp. $20 \mathrm{ff}$.; Fenstra, 1993, pp. $427 \mathrm{ff}$., who also sees a parallel to the criteria of Article $90 \mathrm{EC}$ ).

In our case, the general interest is the insolvency protection, which is not only accepted as a legitimate aim, but has even been demanded by the Package Travel Directive. Where the Community has already set certain standards, there are very tight restrictions with regard to national legislation (Müller-Graf, 1991a). An undertaking that fulfills these standards as prescribed by the implementing law in one Member State must not be made subject to more stringent provisions in another Member State. Where Community legislation is not intended to have an absolute character, but is rather meant as a minimum standard, Member States may adopt more stringent measures, if their legitimate interests are not sufficiently protected by the existing Community rule. ${ }^{44}$ The Package Travel Directive does not set absolute common standards; it states explicitly that "Member States may adopt or return more stringent provisions in the field covered by this directive to protect the consumer." ${ }^{45}$ It is therefore very difficult to give general guidelines as to the compatibility of national legislation in this field. Considering the minimum character of the Directive, Member States will enjoy a rather wide margin of appreciation, as long as it is meant to enhance consumer protection and not abused for a protectionist economic policy.

As far as the market for package travels is concerned, travel orga- 
nizers from Member State A must not be obliged to obtain an additional insolvency protection in Member State B, if they already have sufficient coverage in Member State A (Troberg, 1991, Rz 15-16). Again, what constitutes a sufficient coverage in this context is not the same as sufficient protection under the Directive, because it sets only minimum standards. Therefore the amount of protection required can be decided by Member States themselves, but the additional coverage they demand has to be proportional to the higher protection it affords consumers.

The most elaborate provision on this matter is found in the German Act: ${ }^{46}$ If the main branch of an organizer/retailer is not in Germany but in another Member State, he is nevertheless bound by German law to ensure the claims of the consumer against insolvency. Yet he may do so in accordance with the law of that other Member State, provided a certain minimum standard is guaranteed. Nevertheless the (foreign) organizer/retailer remains bound by German law to prove this security to the consumer.

Looking at the market for selling insolvency protections, a compulsory guarantee fund, whether state-owned or privately owned, seems problematic. It would amount to not only a partial, but practically total entrance barrier for insurance companies from other Member States (Solveen \& Tonner, 1994, pp. 77-78), because all relevant risks are covered by the fund. Such a barrier for foreign insurance companies seems especially problematic (Solveen \& Tonner, 1994, p. 78) with respect to the total liberalization that has taken place in the insurance market through the "Third Directives." 47

\section{Competition Rules}

Articles 85,86 EC. Another provision we have to examine is Article $85 \mathrm{EC}$, concerning anti-competitive agreements between undertakings. Note that it applies only to such agreements, not to state measures. The criteria for an infringement of Article $85 \mathrm{EC}$ are:

1. A collusion between undertakings

2. that affects trade between Member States

3. and has the purpose or effect of restricting competition.

A private guarantee fund will in any case constitute such an agreement between undertakings, be it between the participating travel companies on the one hand or between the banks or insurance companies that own the fund on the other. 
The requirement of an effect on interstate trade is easily fulfilled. In the case of "Cementhandelaren v. Commission"48 the Court ruled that an agreement extending over the whole of the territory of a Member State has the effect of reinforcing national compartmentalization of markets, thereby holding up the desired economic interpenetration. An agreement of such a scope (a whole Member State) therefore, by definition, affects trade between Member States.

Guarantee funds are assumed to have a restrictive effect on competition. As far as organizers/retailers are concerned it could lie in the conditions the fund sets up for membership. These will probably include requirements of minimum capitalization or criteria for assessing the insolvency risk a given undertaking poses. This could make membership impossible for small undertakings or it could be used to discipline competitors (Solveen \& Tonner, 1994, p. 79). The actual effect of such an agreement on the market for package travels depends on the circumstances in the market for insolvency protection and in particular on whether other forms of insolvency protection are available to "outsider" companies (i.e., those travel companies which are not members of the fund) and at what price. In this context it has to be remembered that Article 7 of the Directive (indirectly) obliges travel companies to provide at least some security in any case.

This brings us to the effect of agreements between possible sellers of insolvency protection, i.e., mainly insurance companies. A guarantee fund set up by them will constitute a cooperative joint venture. The undertakings concerned are very unlikely to compete with their own joint venture, even if they do not include this restraint of competition in the agreement. In this context the notices of the Commission on cooperation between enterprises ${ }^{49}$ and on cooperative joint ventures ${ }^{50}$ as well as the group exemption granted by the Commission for cooperation in the insurance sector ${ }^{51}$ might be of interest, but will not answer all the questions arising. However, we shall try to use a more general approach.

For an infringement of Article 85(1) EC a certain qualitative appreciability is required (cf. Ritter, Rawlinson, \& Brown, 1991, pp. 84 ff., with references to relevant case law). The criteria are as follows: Where an agreement that restricts competition

1 . is objectively necessary to protect

2. certain interests recognized as legitimate by the legal system, it is not caught by the prohibition of Article 85(1) EC. Naturally, 
this involves a proportionality test, weighing the protection of the legitimate interest against the restriction of competition.

If in principle an agreement falls under the Prohibition of Article 85(1) EC, the Commission may exempt this agreement, provided it has certain characteristics, which are laid down in Article 85(3) EC. It must contribute to the production or distribution of goods or promote technical or economic progress. Furthermore, a fair share of the benefits created by the agreement must be passed on to consumers. The agreement in question must neither impose restrictions which are not indispensable for achieving these benefits, nor afford the undertaking the possibility of eliminating competition in respect of a substantial part of the products concerned.

The application of these principles, be it with regard to the qualitative appreciability needed to fall under Article 85(1) EC in the first place or a possible exemption under Article 85(3) EC, will result in a proportionality test, weighing the intended or effected restriction of competition against the benefit for consumer protection. Only a few general guidelines can be given, as a definitive assessment very much depends on the details of the contested agreement.

To avoid conflict with the competition rules a guarantee institution should have objective criteria for membership. Every undertaking should be free to participate if it fulfills these criteria. The criteria themselves should be reasonable and restricted to what is indispensable for a proper functioning of the institution; nevertheless the institution may protect itself against prospective participants that are financially dubious or bear a particularly high business risk. Yet this should be done preferably not by refusing admittance, but by demanding higher contributions. Decisions concerning the administration of the institution in general, especially with respect to admitting new members, fixing the required guarantees and contributions, etc., should be subject to clear criteria or even public supervision.

Article $86 \mathrm{EC}$ prohibits the abuse of a dominant position within the Common Market or in a substantial part of it insofar as it may affect trade between Member States. We shall just refer to the guidelines given above for compliance with Article $85 \mathrm{EC}$, adding that an abuse in the sense of Article $86 \mathrm{EC}$ may consist in demanding unreasonably high guarantees for access, arbitrary refusal to admit a newcomer, or discriminatory contributions. Details of the definition of the term "dominant position" are outside the scope of this paper. 
However, an undertaking holding an exclusive right in the sense of Article 90(1) EC has been ruled to hold a dominant position.

As all these considerations apply only to private enterprises, it is important to take a critical look at possible state measures as well.

Articles 3g, 5(2), 85 EC. In the case of "INNO v. ATAB" 52 the Court established the principle of the so-called Article $3 \mathrm{f},{ }^{53} 5(2), 85 / 86$ cases. Accepting that Articles 85 and 86 applied to private undertakings only, the Court used Article 3g and 5(2) EC to draw a duty of Member States not to act against the "effet utile" of the competition rules in Articles 85 and $86 \mathrm{EC}$, for instance by encouraging or reinforcing the effects of agreements between undertakings that were infringing Article 85 or $86 \mathrm{EC}$. This gave rise to the question as to whether such a previous conduct or agreement of private undertakings which had subsequently been reinforced by legislation was required to establish an infringement of Article 3g, 5(2), $85 \mathrm{EC}$ itself; or if it was sufficient for such an infringement that the Member State created a situation by legislation which the undertakings themselves could not have achieved without infringing Article 85 EC.

In November 1993, ${ }^{54}$ the Court resolved the dispute in favour of the first theory in the cases of "Meng" and "Ohra Schadeverzekeringen NV." ${ }^{156}$ Where there have been no private agreements preceding the contested national legislation, ${ }^{57}$ this legislation does not infringe Articles 3g, 5(2), $85 \mathrm{EC}$. "Preceding" has to be interpreted in a very strict sense: a reinforcement of an existing agreement by state regulation can only occur when this regulation "merely takes over the elements of an agreement between competitors in the relevant sector." 58

Thus a Member State will infringe Articles 3g, 5(2) 85 EC if it makes an existing private guarantee fund compulsory, after this fund was prohibited under Article $85 \mathrm{EC}$; but there is no infringement of those provisions if the Member State creates a similar guarantee fund de novo.

However, a Member State must not delegate to private undertakings the fixing of terms at which outsiders may trade, for example leave decisions about the membership requirements for a legally compulsory guarantee fund to an association of organizers/retailers. A nuance of this problem was decided in November 1993, too. In the case of "Bundesanstalt für Güterfernverkehr v. Gebrüder Reiff $\mathrm{GmbH}$ \& $\mathrm{Co} \mathrm{KG}^{\prime \prime 59}$ the facts were the following. 
In Germany the prices for long distance transport of goods are fixed by a commission. The members of this commission are appointed by the Minister of Transport, but are proposed by trade associations. The Court ruled that this did not constitute a prohibited delegation to private entities, because German law provides for specific precautions: The members of the commission act in their own capacity and are therefore not representatives of the respective organizations. When fixing prices they are not allowed to consider the interests of their organizations only, but have to take more general interests into account as well. Last but not least the Minister of Transport can participate in the meetings of the commission and even overrule its decisions.

These criteria may be helpful as guidelines when deciding the extent to which the management of a private guarantee fund should be able to set standards and take decisions that will be legally binding on the entire package travel or insurance industries and the precautions that have to be met in this respect.

Article $90 \mathrm{EC}$. Another restriction of state action in the field of insolvency protection might flow from Article $90 \mathrm{EC}$, which deals with public undertakings and undertakings to which Member States grant special or exclusive rights.

The extent to which Member States are subject to restrictions in establishing monopolies by setting up public undertakings or granting special or exclusive rights to undertakings has been extensively discussed in legal writings as well as in judgements of the Court. A detailed discussion of this most intrinsic issue is outside the scope of this paper; yet we shall attempt to summarize the ongoing dispute as far as it is relevant for our subject.

Article $90 \mathrm{EC}$ strives to avoid circumvention of the Treaty in two respects (cf. Bach, 1992, p. 66). First, it prevents Member States from inducing a conduct of public or privileged undertakings which, if the State itself was acting, would infringe Community rules directed at Member States. Second, it states that Member States must pay due respect to the competition rules when taking measures concerning those undertakings, although the competition rules are aimed at private undertakings.

The crucial question is whether Article 90(1) enshrines specific rules for public undertakings and undertakings that have been granted 
special or exclusive rights, or if to the contrary it merely restates the general rules of the Treaty with respect to those undertakings.

Insofar as the second view is correct, we can restrict ourselves to referring to the considerations given above. A state measure with respect to an undertaking named in Article 90(1) EC must neither restrict the freedom to provide services nor violate the "effet utile" of the competition rules.

If Article 90(1) does in fact put more stringent restrictions on Member State measures aimed at those undertakings than is the case with measures aimed at private ones, the Member State can still justify its measures according to Article 90(2) EC. Undertakings entrusted with the operation of services of general economic interest as well as revenue-producing monopolies are exempted from the application of the Treaty as far as it would obstruct the performance of the tasks assigned to them, on the condition that the development of trade must not be affected to such an extent as would be contrary to Community interests.

This of course boils down to a proportionality test which is very similar to the ones already mentioned (Bach, 1992, pp. $47 \mathrm{ff}$.; Bright, 1993, p. 263; Giesen, 1993, p. 282; Pijnacker Hordijk \& Schmulders, 1993, pp. 414-415). There is some tendency in recent case law of the Court to put more stringent restrictions on Member States policy in the realm of Article 90 than in applying Article $3 \mathrm{f}, 5(2), 85$ (Chung, 1995; Gardner, 1995).

Apart from the Treaty provisions mentioned above, efforts have been made to base a general restriction on the establishment of monopolies by Member States on profound and lengthy studies of the basic principles of the Treaty. Again, although these approaches are unlikely to be accepted by the Court, they will always result in proportionality test.

\section{Liability of Member States for Late Implementation}

After the insolvency of a German travel organizer in the summer of 1993, the question arose as to the liability of the Federal Republic towards travellers hit by this insolvency.

The basis for such a claim had been laid in the "Francovich" case. ${ }^{60}$ There the Italian State did not implement a Directive which obliged Member States to provide for institutions that would secure salary 
claims of employees in the case of the insolvency of their employer. As a consequence the Commission instituted proceedings against Italy which resulted in the declarative decision of the Court of Justice that Italy had infringed Community law by not implementing the Directive. ${ }^{61}$ Later two Italian employees who had lost salaries that should have been protected according to the Directive, sued the Italian State for damages. The Italian court referred this question of a state liability under Community law to the Court of Justice. The Court decided that such a claim existed and gave the following criteria:

1. The Directive must aim at establishing an individual right.

2. The content of this right has to be defined with sufficient precision in the Directive.

3. The damage to the individual has to be caused by the infringement of Community law by the Member State (in casu non-implementation).

In the meantime the Court has confirmed its ruling in the Francovich case in the case of "Miret."

The question of the possible liability of Germany for the late implementation of the package travel directive has produced a massive amount of legal writing (Ewert, 1993; Huff, 1993; Kemper, 1993; Khan, 1993; Löwe, 1993; Schimke, 1993; Solveen \& Tonner, 1994; Tonner, 1993; von Westphalen, 1993). The prevailing opinion is that the criteria of Francovich are fulfilled. The Directive aims at creating an individual right for the consumer. This becomes especially clear from the fact that it provides for the refund of individual payments (von Westphalen, 1993, p. 270). A certain minimum content of this right is defined sufficiently clear by Article 7 of the Directive and has been explained above. As to the causal link between delay in implementation and the damage, some authors submit that such link cannot be established clearly: Even if a Member State had obliged undertakings to provide security, it would still have been up to them to comply with this obligation (Löwe, 1993; Solveen, 1994, p. 62). Indeed, in this respect the final version of the Directive differs from the proposal, ${ }^{63}$ which stated Member States had to ensure that there was "available a guarantee fund for payments." Yet this difference is not necessarily relevant in the context of state liability. As shown above, it would not suffice for Member States to pass the prescribed legislation; they also have to take adequate steps to supervise compliance with it. Yet if there is sufficient supervision, it should be hard for undertakings not to meet its standards. Thus a causal link 
between the delay in implementation (through legislation and efficient control) and the damage to consumers appears to have been established.

Meanwhile, the issue has been put before the ECJ. Several travellers who were hurt by the big insolvency in the summer of 1993 sued the Federal Republic of Germany for damages. The German court (Landgericht Bonn) denied a claim, ${ }^{64}$ but asked the ECJ for a preliminary ruling. ${ }^{65}$ At the time this paper went into the press, the Advocate-General had just concluded that Germany should be held liable. ${ }^{66}$

\section{NOTES}

90/314/EEC; OJ EC 1990 L 158 p. 59.

Art. 9 of the Directive.

3 Ordinance of the Minister for Economic Affairs of 15 november 1994, F G $881 / 1994$.

4 Act of 16 February 1994 on Package Travel and Intermediary Travel Contracts, Monituer Belge 1 April 1994.

5 Law 472 of 30 June 1993 on package travel, L A 30 June 1993; Law 454 of 30 June 1993, amending the Package Travel Guarantee Fund Act 1986, L A 30 June 1993; Government Order 776 of 20 September 1993 on package travels, L A 21 September 1993.

6 Loi no $92 / 645$ du 13/7/92, Journal Officiel du 14/7/92 p. 9457.

7 Gesetz zur Durchführung der Richtlinie des Rates vom 13.6.1990, BGBI 1994 I 1322.

8 Decreto Legislativo of 17 March 1995, 111/95.

9 Loi du 14 juin 1994 portant reglementation des conditions d'exercise des activités relatives à l'organisation et à la vente de voyages ou de séjours et portant transposition de la directive du 13 juin 1990 concernant les voyages, vacances et ciruits à forfait, Mémorial A 58 du 6 juillet 1994, p. 1092.

10 Besluit van 15.1.93, Staatsblad $\mathrm{nr} 43 / 93$ van 28.1 .93 , pp. 1-3; Wet van 24.12.92, Staatsblad nr $689 / 92$ van 30.12 .92 , pp. 1-..5.

3 Decreto-Lei no. 198/93 of 27 May 1993.

12 Package Travel Act, which took effect on 1 January 1993, SFS 1992: 1672; a new Travel Guarantee Act (SFS 1992: 1673) was adopted, taking effect 1 July 1993.

13 Federal Law of 18 June 1993 on package travels, Recueil Officiel 1993 IV 3152.

14 The package travel, package holidays and package tours regulation 1992, statutory instruments 1992 no. 3288.

15 Lov om en rejsegarantifond, $10.4 .1979 \mathrm{nr} 150$, as amended; published by the Ministry of Industry in Industriministeriets lovbekendtgørelse nr 104 af 28.2.1986.

16 See below, section "Different Means of Insolvency Production," subsection "Insurance and Social Security."

17 The existing Act is of 12 June 1981, No 72.

18 The Directive uses the term "organizer or retailer" to define its scope.

19 Cf. Art. 4(6) of the Directive.

20 Art. $4(6)$ b. 


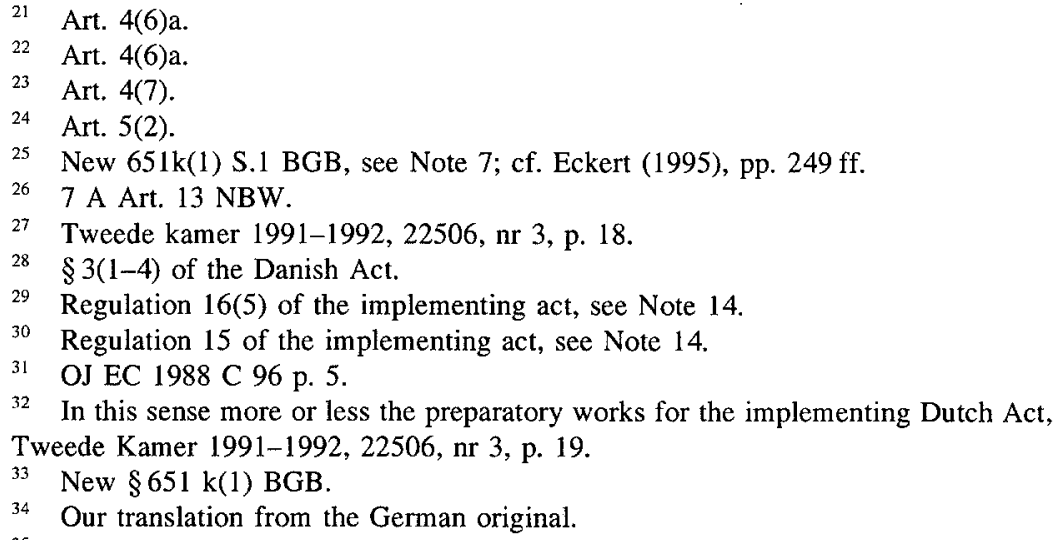


65 LG Bonn: Beschluß 6.6.1994, 1 O 310/93, published in Europäische Zeitschrift Wirtschaftsrecht, 1994, 442 (annotated by Huff, Europäische Zeitschrift für Wirtschaftsrecht, 1994, 446).

${ }_{66}$ See also cases C 46/93 and C 48/93, Brasserie du Pêcheur SA v Germany, and The Queen v Secretary of State for Transport ex parte: Factortame Ltd et al.

\section{REFERENCES}

Bach, A. (1992). Wettbewerbsrechtliche Schranken für staatliche Massnahmen nach europäischem Gemeinschaftsrecht. Tübingen: Mohr.

Bach, A. (1994). Note to cases C 185/91, C 2/91, C 245/91. Common Market Law Review, 31, 1357-1374.

Bright, C. (1993). Article 90, economic policy and the duties of Member States. European Competition Law Review, 14, 263-272.

Chung, C.-M. (1995). The relationship between state regulation and EC-competition law. European Competition Law Review, 16, 87-97.

Dreher, M. (1992). Sicherungseinrichtungen im Kreditsektor zwischen Instituts-, Einlagen- und Herrschaftssicherung. Zeitschrift für Wirtschaftsrecht, 13, 15971612.

Eckert, H. W. (1991). Verbraucherschutz im Reiserecht - Auswirkungen der EGRichtlinie über Pauschalreisen auf das deutsche Recht. Zeitschrift für Rechtspolitik, 24, 454-458.

Eckert, H. W. (1995). Die Risikoverteilung im Pauschalreiserecht. Neuwied: Luchterhand.

Ewert, D. (1993). Schadenersatzpflicht der Bundesrepublik bei Verletzung des europäischen Gemeinschaftsrecht. Recht der internationalen Wirtschaft, 39, 881-887.

Feenstra, J. (1993). Note to cases C 288/89 and C 353/89. Common Market Law Review, $30,424-432$.

Führich, E. R. (1993). Zur Umsetzung der EG-Pauschalreiserichtlinie in deutsches Reisevertragsrecht. Europäische Zeitschrift für Wirtschaftsrecht, 4, 347-352.

Führich, E. R. (1994). Das neue Reiserecht nach der Umsetzung der EG-PauschalreiseRichtlinie. Neue juristische Wochenschrift, 47, 2446-2451.

Gardner, A. (1995). The velvet revolution: Art. 90 and the triumph of the free market in Europe's regulated sectors. European Competition Law Review, 16, 78-86.

Giesen, R. (1993). Statutory monopolies and EC competition law: The Belgian post monopoly case. European Competition Law Review, 14, 279-283.

Graziani-Weiss, W. (1995). Österreichisches Reiserecht. Wien: Verlag Österreich Österreichische Staatsdruckerei.

Huff, M. W. (1993). Sommer, Sonne und die Pleite. Europäische Zeitschrift für Wirtschaftsrecht, 4, 521 .

Huff, M. W. (1994). Note to cases 1 O 317/93, 1 O 310/93 (Landgericht Bonn). Europäische Zeitschrift für Wirtschaftsrecht, 4, 446-447.

Kemper, R. (1993). Ersatzfähigkeit von Ausfallschäden des Reisenden in der Insolvenz des Reiseveranstalters. Neue juristische Wochenschrift, 46, 3293-3298.

Khan, D. E. (1993). Staatshaftung für verpfuschten Urlaub. Neue juristische Wochenschrift, 46, 2646-2649.

Loheac, F. (1994). Le Marché unique de l'Assurance. Revue du Marché commun, $37,592-600$.

López Sanchez, M.-A. (1994). Implementation of EEC consumer protection directives in Spain. Journal of Consumer Policy, 17, 83-99. 
Löwe, W. (1993). Staatshaftung für gescheiterte Billigreisen. Zeitschrift für Wirtschaftsrecht, 14, 1435.

Meyer, J., \& Kubis, S. (1993). Pauschalreiserecht in Europa. Zeitschrift für die vergleichende Rechtswissenschaft, 92, 179-214.

Mölenberg, L. J. H., Olivers, M. L. A. M. J., \& Hallmans, R. R. J. A. (1990). De SGR: gegarandeerd verzekerd? Tijdschrift voor Consumentenrecht, 1990 (5), 346-357.

Möschel, W. (1983) Das Recht der Wettbewerbsbeschränkungen. Köln: Heymann.

Müller-Graf, P. C. (1991a). Rz 14 zu Art. 36 EGV. In: H v.d. Groeben, J. Thiesing, \& C. Ehlermann (Eds.), Kommentar zum EWG-Vertrag, Vol. 1, p. 508. BadenBaden: Nomos.

Müller-Graf, P. C. (1991b). Rz 18 zu Art. 36 EGV. In: H. v. d. Groeben, J. Thiesing, \& C. Ehlermann (Eds.), Kommentar zum EWG-Vertrag, Vol. 1, pp. 497-498. Baden-Baden: Nomos.

Niemeyer, H. J. (1994). Die Anwendbarkeit der Art. 85 und 86 EG-Vertrag auf staatliche Massnahmen. Wirtschaft und Wettbewerb, 44, 721-731.

Pijnacker Hordijk, E. H., \& Smulders, N. M. P. (1993). Note to cases C 41/90, C 260/89, C 179/90. Sociaal-Economische Wetgeving, 41, 406-416.

Randelzhofer, A. (1992). Notes to Art. 60 EC. In: E. Grabitz (Ed.), Kommentar zum EWG-Vertrag. München: Beck.

Reich, N. (1994). The "November Revolution" of the European Court of Justice. Common Market Law Review, 31, 459-492.

Ritter, L. Braun, W. D., \& Rawlinson, R. (1991). EEC competition law. Deventer: Kluwer.

Roberto, V. (1994). Das neue Pauschalreisegesetz. recht, 12, 6-16.

Roth, W. H. (1993). Note to case C 76/90. Common Market Law Review, 30, 145154.

Schimke, M. (1993). Zur Haftung der Bundesrepublik Deutschland gegenüber Bürgern wegen Nichtumsetzung der EG-Richtlinie über Pauschalreisen. Europäische Zeitschrift für Wirtschaftsrecht, 4, 698-702.

Solveen, K., \& Tonner, K. (1994). Neues Reiserecht. Köln: Verlag Kommunikationsforum Recht, Wirtschaft, Steuern (RWS).

Tonner, K. (1992). Reiserecht in Europa. Neuwied: Luchterhand.

Tonner, K. (1993a). Harmonisierung oder Disharmonisierung des Reiserechts. Europäisches Wirtschafts- und Steuerrecht, 4, 197-202.

Tonner, K. (1993b). Staatshaftung wegen verspäteter Umsetzung der Pauschalreiserichtlinie. Zeitschrift für Wirtschaftsrecht, 14, 1205-1210.

Troberg, P. (1991). Rz 15 f zu Art. 59 EGV. In: H. v.d. Groeben, J. Thiesing, \& C. Ehlermann (Eds.), Kommentar zum EWG-Vertrag, Vol. 1, p. 1060. Baden-Baden: Nomos.

von Westphalen, F. (1993). Staatshaftung bei Nichtdurchführung einer EG-Richtlinie. Europäisches Wirtschafts- und Steuerrecht, 4, 269-272.

\section{ZUSAMMENFASSUNG}

Garantiefonds für die Reisebranche: Schutz des Verbrauchers bei Insolvenz seines Reiseveranstalters oder -büros. Die EG-Pauschalreiserichtline befaßt sich unter anderem mit dem Insolvenzproblem: Reisende sitzen am Urlaubsort fest, wenn ihr Reiseveranstalter plötzlich zahlungsunfähig wird. Die letzten Insolvenzen großer 
österreichischer und deutscher Reiseveranstalter zeigen die praktische Bedeutung dieses Problems. Der Beitrag argumentiert zunächst rechtspolitisch, daß und warum Reisende gegen dieses Insolvenzrisiko geschützt werden sollten. Dann werden verschiedene Möglichkeiten der Insolvenzabsicherung und damit der Umsetzung der Richtline erläutert. Insbesondere werden behandelt: der Umfang der Absicherung, die Pflichten von Veranstalter und Reisebüro, die freie Wahl der Sicherungsmittel, Garantiefonds, private Versicherung und Sozialversicherung, Bankgarantien, Treuhandschaften und andere Sicherungsmittel, sowie Implikationen aus dem Europarecht. Es wird der Standpunkt vertreten, daß die Mitgliedstaaten einen höheren Schutzstandard vorsehen sollten als den Minimalstandard der Richtline. Der Reisende sollte auch einen Anspruch auf Ersatz seines immateriellen Schadens sowie reinen Vermögensschadens haben, wie etwa die höheren Kosten einer Ersatzreise. Auch sollte die Rückerstattung von Anzahlungen nicht auf die Zeit vor Reiseantritt beschränkt werden. Dem Reisenden sollten seine höheren Aufwendungen ersetzt werden, wenn er am Urlaubsort bleiben will. Schließlich sollte der Reisende in der Lage sein, seine Rückreise gegen Kostenersatz selbst zu organisieren. Bezüglich verspäteter Umsetzung der Richtline wird die Ansicht vertreten, daß Mitgliedstaaten für daraus erwachsende Schäden dem Reisenden gegenüber haften.

\section{THE AUTHORS}

Harald Halbhuber has a law degree from the University of Vienna. During his studies he spent one term at the University of Utrecht as an Erasmus exchange student. His address is: Hietzinger Hauptstrasse 109, A-1130 Wien. Ewoud Hondius is Professor of Civil Law at the University of Utrecht. His address is: Molengraaff Instituut voor Privatrecht, Nobelstraat 2A, 3512 EN Utrecht, Netherlands. 